\title{
Antibacterial activity and sensory characteristic of sauce for raw fish with tea extract and garlic vinegar
}

\author{
Young Sun Han ${ }^{1 *}$, Hye Jin Choi ${ }^{1}$, Seung Ri Lee ${ }^{1}$, Mun-Ju Kwon ${ }^{1}$, Myung Je Heo ${ }^{1}$, \\ $\mathrm{Nam}^{-\mathrm{Gyu}} \mathrm{Jo}^{1}$, Hye Young Kim ${ }^{2}$ \\ ${ }^{1}$ Incheon Research Institute of Public Health and Environment, Incheon 22320, Korea \\ ${ }^{2}$ Ganghwa Agricultural Technology Service Center, Incheon 23038, Korea
}

\section{차추출물과 마늘식초를 이용한 생선회용 소스의 항균활성 및 관능특성}

\author{
한영선 $^{1 *} \cdot$ 최혜진 ${ }^{1} \cdot$ 이승리 ${ }^{1} \cdot$ 권문주 $^{1} \cdot$ 허명제 $^{1} \cdot$ 조남규 $^{1} \cdot$ 김혜영 $^{2}$ \\ ${ }^{1}$ 인천광역시 보건환경연구원, ${ }^{2}$ 강화군 농업기술센터
}

\begin{abstract}
This study was conducted to investigate the antibacterial activities and sensory properties of a sauce containing tea extract and garlic vineger against raw fish. The sauce was evaluated antibacterial activity against Vibrio parahaemolyticus and Vibrio vulnificus which is considered as one of the major food bome pathogens. As a result, the sauce inhibited the growth of $V$. parahaemolyticus and $V$. vulnificus distinctly. In addition, the sauce with soy sauce and Kochujang showed the restricted growth of Vibrio parahaemolyticus and Vibrio vulnificus in sliced raw flatfish. Sensory evaluations were measured by 7-point hedonic scale using sliced raw flatfish with the sauce mixed with Kochujang and soy sauce. The score of texture in the sauce with Kochujang was significantly higher than that of regular Chokochujang (p<0.05). Moreover, total preference including appearance, texture, aroma and taste were significantly higher in the sauce with soy sauce than those of regular soy sauce $(p<0.05)$. Consequently, the soy sauce with tea extract and garlic vinegar may enhance the satisfaction of consumer and antimicrobial activity that against $V$. parahaemolyticus and $V$. vulnificus, resulting in potential reduction the outbreaks of food bome pathogens.
\end{abstract}

Key words : antibacterial activity, sauce for raw fish, tea extract, Vibrio parahaemolyticus, Vibrio vulnificus

\section{서 론}

우리나라는 삼면이 바다로 둘러 싸여 수산 생물의 자원 이 풍부하고 그 중 어패류가 차지하는 비율이 높다. 이와 비례하여 해산물에 의한 식중독 사고 위험성이 높은데 특히 그 위험성은 여름철 식중독으로 두드러지게 나타난다. 주 병원체로는 Vibrio, Escherichia, Salomonella 속 등이며, 이 들 중 Vibrio 속은 담수에서 해수까지 넓은 수역에서 검출되

*Corresponding author. E-mail : violet04@korea.kr Phone : 82-32-440-5462, Fax : 82-32-440-5494

Received 21 March 2016; Revised 10 June 2016; Accepted 4 July 2016.

Copyright (c) The Korean Society of Food Preservation. All rights reserved.
는 그람 음성의 종속 영양 세균으로서 극지방을 제외한 전세계 수역에서 광범위 하게 검출 되고 있으며 여름철 생선회 식중독을 유발하는 주 원인균은 Vibrio 속이다 $(1,2)$ 특히 우리나라 서해안과 강 하구에서 빈번히 문제가 되는 병원성종으로는 Vibrio parahaemolyticus, Vibrio vulnificus 등이 있으며 이들에 의해 단일 발병 하는 경우도 있으나 혼합 감염으로 인한 식중독 사례도 보고 된 바 있다(1). 해산물을 생식하는 식습관을 가진 우리나라에서는 이러한 미생물에 오염된 생선회를 먹고 패혈증 및 식중독이 발생하 는 사건이 빈번하여 그 대책이 시급하다 $(3,4)$.

소스(Sauce)는 고대 로마시대부터 음식의 맛과 색을 향 상시키기 위해 사용해온 액체, 유동상의 조미료이며, 현재 까지 알려진 바로는 500여 종류에 달하는 것으로 알려져 있다(5). 이러한 소스는 예전부터 냉장, 냉동 시설이 완벽하 
지 못할 경우 고기의 맛을 돋우거나 변질 위험이 있는 음식 의 맛을 증진시키고 소비를 촉진시키기 위해 개발 한 것으 로 추측된다(6). 그리하여 각각의 민족별로 다양한 재료를 활용하여 소스를 만들고자 하는 노력이 있어왔다.

마늘(Allium sativum L)은 전 세계적으로 널리 이용되고 있는 향신료로서 특히 우리나라에서는 조미용 기호식품으 로 김치류를 비롯한 대부분의 요리에 널리 이용되고 있다. 또한 마늘은 그 특유의 맛과 향뿐만 아니라 allicin, dially disulfide와 같은 1,2 차 생성물인 thiosulfinate기가 생리적으 로 중요한 $-\mathrm{SH}$ 기와 강하게 반응하여 각종 효능을 나타내고, thiamin의 체내작용을 높여주는 등 독특한 생리적 활성을 갖고 있어 다양하게 활용이 가능하다(7). 최근 건강증진에 대한 소비자들의 관심이 고조되면서 마늘을 이용한 다양한 상품이 개발, 출시되고 있다. 마늘을 이용한 가공 생산량은 1998 년 2,231 톤에서 2008년에는 33,809 톤으로 15배 이상 크게 증가하였으며(8), 마늘 분말, 다진 마늘, 마늘 통조림 등 소비자의 편의에 맞는 다양한 제품이 개발되고 있다(9).

고대부터 식품의 안전성과 저장성을 높이기 위해 미생물 증식을 억제할 수 있는 천연 물질을 첨가하였으며, 근래에 는 식품의 부패와 변질을 방지하여 식중독을 예방할 수 있도록 식품 첨가물로써 합성 보존료를 널리 이용하고 있 다. 그러나 건강에 대한 관심이 높아진 최근, 항균 및 항산화 기능을 가질 뿐만 아니라 식품의 향미증진에 기여하고 더 다양한 생리활성을 갖는 천연 물질을 사용하고자 하는 소비 자들의 움직임이 활발하다. 이에 항균 및 항산화 효과를 갖는 천연 식품 성분에 대한 연구들이 전 세계적으로 진행 되고 있으며, 그 중 polyphenol, tocopherol, 차추출물 등은 이러한 기능성을 갖는 대표적인 물질로 잘 알려져 있다 (10-12). 차추출물은 그 항균 및 항산화 효과가 활발하게 보고되고 있으며, 실제로 식품에 널리 이용되고 있다 (13-17). 그 중에서도 녹차 추출물은 다양한 종류의 세균에 대하여 사멸 효과가 뛰어나며, 특히 Staphylococcus aureus, Aeromonas hydrophilia에 대하여 일반 보존료(sodium benzoate)보다도 강한 항균활성을 나타내기도 하는 등 우수 한 항균 작용을 나타낸다는 연구 보고도 있으며(14), 이러한 결과로 미루어 차추출물은 천연 보존료로서의 활용 가치가 뛰어날 것으로 판단된다.

이러한 관점에서 본 연구에서는 천연 보존료 역할을 하 는 차추출물을 이용하여 항균활성을 향상시킴과 동시에 마늘식초를 이용하여 맛과 기능성을 모두 향상시킨 생선회 용 소스를 제조하고자 하였다. 그에 따라 식중독 균에 대한 생선회용 소스의 항균활성과 관능특성을 평가하였다. 따라 서 본 연구는 여름철 빈번히 일어나는 생선회 섭취로 인한 식중독을 예방하고 생선회 소비를 촉진하는 데에도 도움을 줄 수 있을 것으로 예상된다.

\section{재료 및 방법}

생선회용 소스의 제조 및 이화학 특성 측정

마늘을 이용한 발효식초는 물 $3.6 \mathrm{~L}$, 생막걸리(Sosungju; Incheon Takju, Incheon, Korea) $3.75 \mathrm{~L}$, 소주(Hite Jinro Co., Ltd., Icheon, Korea) $0.3 \mathrm{~L}$, 마늘(Ganghwa, Korea) $10 \mathrm{~kg}$, 생강(Korea) $0.3 \mathrm{~kg}$, 천일염(Hanju Co., Ltd., Ulsan, Korea) $0.1 \mathrm{~kg}$, 설탕 $(\mathrm{CJ}$ cheiljedang, Incheon, Korea) $5 \mathrm{~kg}$ 을 넣어 잘 혼합한 후 2 주 동안 $40^{\circ} \mathrm{C}$ 에서 2 주간 1 차 발효 시킨 후 $20^{\circ} \mathrm{C}$ 에서 3 개월간 2 차 발효 시켜 사용하였다. 이렇게 만든 마늘 식초 $500 \mathrm{~mL}$ 에 차나무 잎 열수 추출물(카테킨 함량 $80 \%$ 이상, Camellia sinensis, Zhejiang, China)을 $3 \mathrm{~g}$ 녹인 정제수 $0.5 \mathrm{~L}$ 을 혼합하여 침전물을 걸러내어 생선회용 소스 로 제조하였다

생선회용 소스를 실제 생선회에 적용시킨 순간살균력 평가 및 관능평가에 사용하기 위해서 상기 방법대로 제조한 생선회용 소스를 간장 또는 고추장과 1:1로 혼합하여 사용 할 경우에는 차추출물 함량을 2 배 높여 최종 소스 제조 후 항균소스 함량이 $0.3 \%$ 가 되도록 제조하였다. 이 때 생선 회용 소스와 시판 간장을 $1: 1$ 로 혼합하여 간장-생선회용 소스를, 생선회용 소스와 시판 고추장을 1:1로 혼합하여 고추장-생선회용 소스를 제조하여 생선회에 적용한 순간살 균력 평가 및 관능평가에 사용하였다.

마늘식초와 차추출물을 첨가한 생선회용 소스의 이화학 적 품질특성을 알아보기 위해 $\mathrm{pH}$, 당도 및 총산을 측정하였 다. $\mathrm{pH}$ 는 $\mathrm{pH}$ meter(Sartorius Docu-pH meter, Sartorius, Goettingen, Germany)를 사용하여 3회 반복 측정하였다. 당 도는 굴절당도계(DR-A1, Atago Co., Ltd., Tokyo, Japan)를 이용하였고 3 회 반복 측정하여 평균값을 가용성 고형분 함량( $\left.{ }^{\circ} \mathrm{Brix}\right)$ 으로 표시하였다. 총산은 시료액 $10 \mathrm{~mL}$ 에 끓여 서 식힌 물을 가하여 $100 \mathrm{~mL}$ 로 하고 그 $20 \mathrm{~mL}$ 를 페놀프탈레 인시액을 지시약으로 하여 $0.1 \mathrm{~N}$ 수산화나트륨액으로 적정 한 량 $(\mathrm{mL})$ 을 초산(Acetic acid) 함량(\%)으로 환산하여 나타 내었다.

\section{사용균주 및 배지}

생선회용 소스의 항균활성 측정을 위해 사용된 미생물 균주는 Vibrio parahaemolyticus NCCP 11133(V. parahaemolyticus), Vibrio vulnificus NCCP 11135(V. vulnificus)이며 이들은 질 병관리본부 국립보건연구원 국가병원체자원은행(National Culture Collection for Pathogens; NCCP, Cheongju, Korea)으 로부터 구입 - 분양받았다. 사용된 배지는 tryptic soy agar(TSA; Difco, Becton Dickinson and company, spark, New Jersey, USA)를 사용하였다.

차추출물 함량에 따른 생선회용 소스의 항균활성 측정 생선회용 소스 내에서 최적의 항균활성을 나타내는 차추 
출물 함량을 알기 위해, paper disk diffusion method를 이용 하여(18) 차추출물 함량이 $0 \%$ 인 것을 대조군으로 설정하 고, $0.1 \%, 0.3 \%, 0.5 \%$ 에 따른 $V$. parahaemolyticus와 $V$. vulnificus 균주에 대한 생육저해환(clear zone) 직경 $(\mathrm{mm})$ 을 측정하였다.

\section{타 장류와 생선회용 소스 간 항균활성 비교 측정}

항균활성 비교 검사는 paper disk diffusion method를 수정 하여 실험하였다. 실험 균주를 $1 \% \mathrm{NaCl}$ 을 첨가한 Nutrient $\operatorname{agar(Difco)}$ 에 2 3세대 계대 배양하고 $37^{\circ} \mathrm{C}$ 항온기에서 24 시간 배양하여 활성화 시킨 후 사용하였다. 대수증식기의 균체를 Mcfarland 1.0로 맞춘 후 멸균된 Mueller-Hinton $\operatorname{argar(Difco)}$ 에 균일하게 도말하였다. 멸균된 $6 \mathrm{~mm}$ filter paper disc를 상면에 가볍게 고정시키고 $20 \mu \mathrm{L}$ 의 생선회용 소스, 시판 간장(CJ cheiljedang), 시판 고추장(CJ cheiljedang)을 각각 분주하여 $37^{\circ} \mathrm{C}$ 에서 24 시간 배양 하여 생육저해환 생성 여부를 검사하였다.

생선회용 소스의 순간살균효과 측정

배양한 V. parahaemolyticus, V. vulnificus를 Macfarland 0.5로 조정한 후, $1 \%$ Alkaline peptone water(APW) 액체배지 로 $10^{-1}, 10^{-2}, 10^{-3}, 10^{-4}$ 배 희석하여 집락수(colony)가 200 500이 되는 $10^{-3}$ 배로 희석한 균배양액 $100 \mu \mathrm{L}$ 를 접종하 여 대조군(control)으로 하였다. V. parahaemolyticus와 $V$. vulnificus 각각의 배양액과 생선회용 소스 $100 \mu \mathrm{L}$ 씩(1:1)을 10초간 처리 후 Thiosulfate citrate bile salts sucrose $\operatorname{agar(TCBS)}$ 배지에 표면도말법을 이용하여 $37^{\circ} \mathrm{C}$ 에서 24시 간 배양한 후 균수를 측정하였다.

\section{실제 생선회에 적용한 생선회용 소스의 순간살균효과 측정}

배양한 V. parahaemolyticus, V. vulnificus를 Macfarland 1.0 으로 조정한 후, $1 \% \mathrm{APW}$ 액체배지를 이용하여 $10^{-3}$ 배로 단계 희석한 균배양액 $100 \mu \mathrm{L}$ 을 각각 광어회(sliced raw flatfish; Soraepogu fish market, Incheon, Korea) 한쪽 부분에 접종한 후 $\mathrm{TCBS}$ 선택배지에 골고루 바른 뒤, $37^{\circ} \mathrm{C}$ 에서 24 시 간 배양한 후 관찰하여 대조군(control)으로 하였다.

그리고 실제 생선회 섭취 시의 전통적인 식습관을 고려 하여, 생선회용 소스와 시판 간장(CJ cheiljedang) 및 시판 고추장(CJ cheiljedang)을 각각 1:1로 혼합하여 간장-생선회 용 소스 및 고추장-생선회용 소스를 제작하였다. 이렇게 제작한 각각의 소스 $500 \mu \mathrm{L}$ 씩을 균배양액 $100 \mu \mathrm{L}$ 씩을 접종 한 광어회에 골고루 바른 후 즉시 TCBS 선택배지에 발라서 $37^{\circ} \mathrm{C}$ 에서 24 시간 배양한 후 관찰하였다.

생선회용 소스의 관능특성 평가

일반적으로 횟집에서 제공하는 생선회용 믹스 간장 (Woomtree, Pocheon, Korea) 및 초고추장(Purune food,
Incheon, Korea)을 대조군으로 설정하고, 시판 간장(CJ cheiljedang) 및 고추장(CJ cheiljedang)에 생선회용 소스를 혼합한 간장-생선회용 소스 및 고추장-생선회용 소스를 실 험군으로 설정하여 그 기호성에 대해 인천광역시 보건환경 연구원 직원 37 명을 대상으로 관능평가를 수행하였다. 평 가는 블라인드 테스트(blind test)방법으로 광어회, 물과 함 께 제시하여 진행하였다. 각각의 소스에 대한 외관, 조직감, 향미, 맛, 종합적 기호도 등 5가지 관능 특성을 7점 척도법 (매우 나쁘다 1 , 나쁘다 2, 나쁜편이다 3 , 보통이다 4, 좋은편 이다 5 , 좋다 6 , 매우 좋다 7)에 의해 평가하였다.

\section{통계 처리}

실험결과는 3회 반복으로 행하여 평균 \pm 표준편차로 나타 내었으며, 관능검사 결과는 통계분석용 SPSS(18.0, SPSS Inc, Chicago, IL, USA) package program을 이용하여 통계처 리 하였으며 각 항목에 대한 각각의 대조군과 실험군 간의 유의성은 $\mathrm{p}<0.05$ 수준에서 paired T-test로 검정하였다.

\section{결과 및 고찰}

\section{차추출물 함량에 따른 생선회용 소스의 항균활성}

생선회용 소스의 항균활성을 나타내는 가장 중요한 재료 인 차추출물의 함량에 따른 생육저해환의 직경은 Table 1에 서 보는 바와 같다. 차추출물의 함량이 $0.1 \%$ 일 때, $V$. parahaemolyticus에 대한 생육저해환 직경은 $8.3 \mathrm{~mm}$ 였으 며, $0.3 \%$ 일 때 $12.2 \mathrm{~mm}, 0.5 \%$ 일 때는 $13.3 \mathrm{~mm}$ 로 측정되었 다. V. vulnificus의 경우, 차추출물 함량이 $0.1 \%$ 일 때 11.3 $\mathrm{mm}, 0.3 \%$ 일 때 $15.0 \mathrm{~mm}, 0.5 \%$ 일 때 $17.3 \mathrm{~mm}$ 로 측정되었다. 즉, V. parahaemolyticus 및 V. vulnificus에 대한 차추출물의 항균활성은 차추출물의 함량이 높아질수록 증가하는 양상 을 보였다. Xi 등(19)의 연구에서도 차추출물의 함량에 따라 V. parahaemolyticus의 생육이 억제됨을 확인할 수 있었으 며, 본 연구에서는 $V$. vulnificus 또한 같은 양상을 보인다는 것을 알 수 있었다.

차추출물 함량이 $0.1 \%$ 에서 $0.3 \%$ 로 증가될 때의 두 균주 에 대한 항균력 증가폭이 $0.3 \%$ 에서 $0.5 \%$ 로의 증가폭에 비 해 높은 것으로 측정되었다. 또한 차추출물의 함량이 늘어

Table 1. Antibacterial activity of tea extract

\begin{tabular}{ccc}
\hline \multirow{2}{*}{$\begin{array}{c}\text { Tea extract } \\
\text { concentration }(\%)\end{array}$} & \multicolumn{2}{c}{ Diameter of clear zone $(\mathrm{mm})$} \\
\cline { 2 - 3 } & Vibrio parahaemolyticus & Vibrio vulnificus \\
\hline 0 (Control) & $6.0 \pm 0.0^{1)}$ & $6.0 \pm 0.0$ \\
0.1 & $8.3 \pm 0.6$ & $11.3 \pm 0.6$ \\
0.3 & $12.2 \pm 0.3$ & $15.0 \pm 0.0$ \\
0.5 & $13.3 \pm 0.6$ & $17.3 \pm 0.6$ \\
\hline
\end{tabular}

${ }^{11}$ All values are means \pm SD 
날수록 차추출물 고유의 떫은맛이 나타남을 고려했을 때 생선회용 소스에서의 차추출물 함량을 $0.3 \%$ 로 설정하는 것이 가장 효율적이라고 판단하였다. 차추출물 함량을 $0.3 \%$ 로 제조한 생선회용 소스의 이화학적 지표를 확인한 결과, $15^{\circ} \mathrm{C}$ 에서 $\mathrm{pH}$ 는 $3.57 \pm 0.02$, 당도는 $21.9 \pm 0.0{ }^{\circ} \mathrm{Brix}$, 총 산은 $1.15 \pm 0.01 \%$ 였다(data not shown).

한편 생선회 식중독 발생에 주요 원인균이 되는 Vibrio 속 외에도 일반 식중독의 원인균에 대한 차추출물의 항균활 성에 대한 연구들이 많이 보고된 바 있다. 특히 Chung 등(20) 은 V. parahaemolyticus를 비롯한 Salmonella typhimurium Staphylococcus aureus 등 8종의 식중독균에 대해 disc 확산 법 등을 이용한 차추출물의 균주 생육저해 효과를 보고하였 으며, 녹차 추출물의 Escherichia coli $\mathrm{O} 157: \mathrm{H} 7$ 에 대한 항균 효과(21)와 Listeria monocytogenes에 대한 증식제어효과 (22), 그 외에도 다양한 일반 식중독 균에 대한 항균활성(14, 23) 연구가 보고되었다. 이와 같이 차추출물을 함유하는 생선회용 소스가 생선회 식중독 원인균뿐만 아니라 일반 식중독 균에 대한 항균효과를 나타낼 가능성이 있으며, 이 를 확인하기 위한 추가적인 연구가 필요할 것으로 보인다. 만약 다양한 식중독 원인균에 대한 생선회용 소스의 항균효 과가 입증된다면 더욱 다양한 음식과 소스에의 활용이 가능 할 것으로 판단된다.

타 장류와 생선회용 소스 간 항균활성 비교

시중에 판매되는 간장, 고추장과 제작한 생선회용 소스 의 항균활성을 비교 평가하기 위해 V.parahaemolyticus, V. vulnificus 균주를 이용하여 생육저해환 형성 유무를 관찰 하였다. 그 결과 Fig. 1에서와 같이 생선회용 소스에 대해서 만 생육저해환이 형성되었고 시판 간장과 고추장에서는 생육저해환을 형성하지 않았을 뿐만 아니라 오히려 disk 주변에 다수의 미생물이 증식되었음을 확인하였다. 이는 간장, 고추장이 발효식품인 만큼 곰팡이나 효모와 같은 각 각의 제품 발효와 관련된 미생물일 것으로 사료된다.
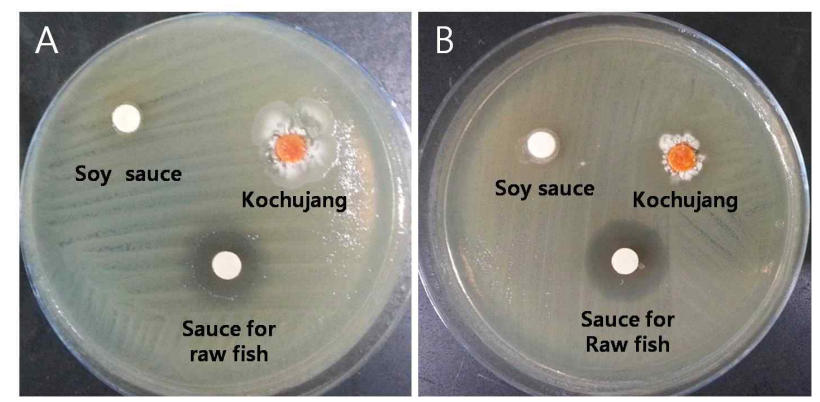

Fig. 1. Antibacterial activities of the sauce for raw fish (containing $0.3 \%$ of tea extract), soy sauce and Kochujang.

A, Vibrio parahaemolyticus, B, Vibrio vulnificus.

생선회용 소스의 순간살균효과

생선회 식중독의 원인균인 $V$. parahaemolyticus, $V$. vulnificus에 대한 생선회용 소스의 순간살균효과를 본 결과 는 Table 2, Fig. 2와 같았다. 즉, V. parahaemolyticus, $V$. vulnificus는 생선회용 소스에서 증식이 억제되었으며 이는 생선회용 소스가 뚜렷한 살균 효과를 나타내는 것으로 사료 되어진다.
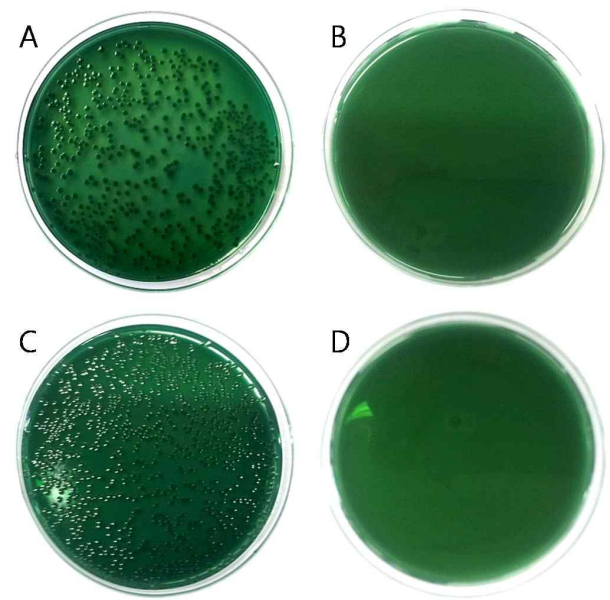

Fig. 2. Survival of Vibrio parahaemolyticus and Vibrio vulnificus treated with the sauce for raw fish for 10 seconds.

A, Vibrio parahaemolyticus Control; B, Vibrio parahaemolyticus Sauce for raw fish; C, Vibrio vulnificus Control; D, Vibrio vulnificus Sauce for raw fish.
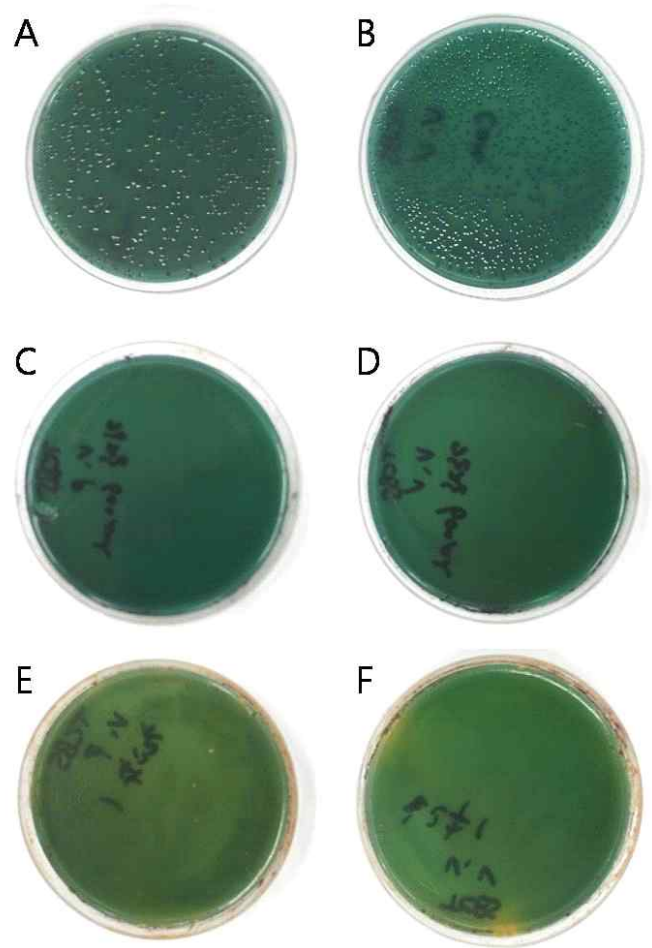

Fig. 3. Survival of Vibrio parahaemolyticus and Vibrio vulnificus on sliced raw flatfish treated with soy and Kochujang sauces for raw fish.

A, Vibrio parahaemolyticus Control; B, Vibrio vulnificus Control; C, Vibrio parahaemolyticus Soy sauce+Sauce for raw fish (1:1); D, Vibrio vulnificus Soy sauce+Sauce for raw fish (1:1); E, Vibrio parahaemolyticus Kochujang+Sauce for raw fish (1:1); F, Vibrio vulnificus Kochujang+Sauce for raw fish (1:1). 
Table 2. Survival of Vibrio parahaemolyticus and Vibrio vulnificus treated with the sauce for raw fish for 10 seconds

\begin{tabular}{ccc}
\hline \multirow{2}{*}{ Strains } & \multicolumn{2}{c}{ Viable cell count $(\mathrm{CFU} / \mathrm{mL})$} \\
\cline { 2 - 3 } & Control & Sauce for raw fish \\
\hline Vibrio parahaemolyticus & $2.8 \times 10^{3}$ & $\mathrm{NG}^{1)}$ \\
Vibrio vulnificus & $3.8 \times 10^{3}$ & $\mathrm{NG}$ \\
\hline
\end{tabular}

${ }^{1)}$ No growth.

실제 생선회에 적용한 생선회용 소스의 순간살균효과

생선회 섭취 시의 전통적인 식습관을 고려하여 제조한 간장-생선회용 소스와 고추장-생선회용 소스를 광어회에 적용하여 $V$. parahaemolyticus, V. vulnificus 균주 각각에 대한 순간살균효과를 측정하였다. 그 결과, Table $3, \mathrm{Fig}$. 3 에서와 같이 두 가지 소스 모두에서 V. parahaemolyticus, V. vulnificus의 증식이 억제됨을 확인하였다. 이로써 생선회 용 소스는 실제 생선회 섭취 시에도 V. parahaemolyticus, V. vulnificus 균주에 대해 살균효과를 나타낸다는 것을 확인 하였고, 생선회용 소스가 실제 생선회 섭취 시 유용하게 활용될 수 있을 것이라 판단된다. 또한 $\mathrm{Kim}$ 등(24)은 녹차를 비롯한 천연산물을 배합하여 제조한 고추장에 식초를 첨가 한 결과 V. parahaemolyticus의 생육저해 효과가 우수하게 나타났다고 보고하였는데 이는 본 연구결과와 유사함을 보여주었다.

Table 3. Survival of Vibrio parahaemolyticus and Vibrio vulnificus on sliced raw flatfish treated with soy and Kochujang sauces for raw fish

\begin{tabular}{cccc}
\hline \multirow{2}{*}{ Strains } & \multicolumn{3}{c}{ Viable cell count (CFU/mL) } \\
\cline { 2 - 4 } & Control & $\begin{array}{c}\text { Soy sauce }+ \\
\text { Sauce for raw } \\
\text { fish (1:1) }\end{array}$ & $\begin{array}{c}\text { Kochujang }+ \\
\text { Sauce for raw } \\
\text { fish (1:1) }\end{array}$ \\
\hline Vibrio parahaemolyticus & $4.8 \times 10^{5}$ & $\mathrm{NG}^{1)}$ & $\mathrm{NG}$ \\
Vibrio vulnificus & $8.0 \times 10^{5}$ & $\mathrm{NG}$ & $\mathrm{NG}$ \\
\hline
\end{tabular}

${ }^{1)}$ No growth.

\section{생선회용 소스의 관능적 특성 비교}

광어회를 이용하여 대조군과 실험군 간 관능 특성을 평 가한 결과는 Table 4와 같았다. 먼저 생선회용 소스 자체의 관능 평가에서는 어떠한 처리도 하지 않은 대조군(A)과 생선회용 소스만을 회에 뿌린 실험군(B)의 관능 특성을 비교한 결과, 조직감, 맛, 종합 기호도 측면에서 $\mathrm{A}$ 군보다 $\mathrm{B}$ 군에서 높은 점수를 받았으며 특히 맛과 종합 기호도 측면에서는 $95 \%$ 신뢰 수준에서 통계적으로 유의한 차이가 있었다.

고추장-생선회용 소스의 관능 특성을 알아보기 위해, 일 반적으로 횟집에서 제 공되는 초고추장을 대조군 $(\mathrm{C})$ 으로 설정하고 시판 고추장과 항균소스를 $1: 1$ 로 혼합한 고추장-
생선회용 소스를 실험군(D)으로 하여 비교한 결과, D군은 외관, 조직감, 향미, 맛, 종합 기호도 등 모든 측면에서 $\mathrm{C}$ 군 보다 높은 점수를 얻었으나, 조직감 항목에서만 $95 \%$ 신뢰 수준에서 통계적으로 유의한 차이가 있는 것으로 나타났 다. 이는 피실험자들이 외관, 향미, 맛, 종합적 기호도 항목 에 대해 일반적으로 사용하는 초고추장과 고추장-생선회용 소스 간의 유의적 차이를 느끼지 못하는 것으로 판단되며, 이를 통해 시중 판매되는 초고추장을 고추장-생선회용 소 스로 대체하더라도 거부감 없이 수용할 수 있을 것이라 판단된다.

마지막으로 간장-생선회용 소스의 관능 특성을 평가하 기 위해, 일반적으로 횟집에서 제공되는 생선회용 믹스 간 장을 대조군 $(\mathrm{E})$ 로 설정하고 시판 간장과 생선회용 소스를 $1: 1$ 로 혼합한 간장-생선회용 소스를 실험군 $(\mathrm{F})$ 로 설정하여 그 관능 특성을 비교하였다. 그 결과 $\mathrm{F}$ 군의 외관은 4.92점, 조직감은 4.86점, 향미는 4.70점, 맛은 4.76점으로, $\mathrm{E}$ 군의 외관이 4.49점, 조직감이 4.35점, 향미가 4.0점, 맛이 4.08점 인 것에 비해 모든 항목에서 우수한 관능 특성을 나타냈으 며, 종합 기호도 역시 $\mathrm{E}$ 군의 4.08점에 비해 $\mathrm{F}$ 군은 4.70점으 로 월등히 우수하게 평가 되었다. 그리고 5가지 평가항목 모두에서 $95 \%$ 신뢰수준에서 통계적으로 유의한 차이를 보였다. 이로 인해 간장-생선회용 소스로의 대체가 항균 기능성을 높임과 동시에 소비자의 만족도도 증대시킬 수 있을 것으로 사료된다.

Table 4. Sensory characteristics of soy sauce and Chokochujang sauces for raw fish

\begin{tabular}{|c|c|c|c|c|c|c|}
\hline \multirow{2}{*}{ Characteristics } & \multicolumn{2}{|c|}{ Sauce for raw fish } & \multicolumn{2}{|c|}{ Chokochujang } & \multicolumn{2}{|c|}{ Soy sauce } \\
\hline & $A^{1)}$ & B & $\mathrm{C}$ & $\mathrm{D}$ & E & $\mathrm{F}$ \\
\hline Apper & $5.08 \pm 1.19^{2)}$ & $5.00 \pm 1.20$ & $4.86 \pm 1.06$ & $4.92 \pm 1.14$ & $4.49 \pm 1.26$ & $4.92 \pm 1.19^{*}$ \\
\hline Texture & $4.86 \pm 1.16$ & $4.95 \pm 1.15$ & $4.73 \pm 1.15$ & $5.05 \pm 1.08^{*}$ & $4.35 \pm 1.14$ & $4.86 \pm 1.23^{*}$ \\
\hline Aroma & - & - & $4.38 \pm 1.09$ & $4.59 \pm 1.19$ & $4.00 \pm 0.94$ & $4.70 \pm 1.18^{*}$ \\
\hline Taste & $4.22 \pm 1.29$ & $4.65 \pm 1.34^{\star 2)}$ & $4.41 \pm 1.30$ & $4.70 \pm 1.35$ & $4.08 \pm 0.92$ & $4.76 \pm 1.28^{*}$ \\
\hline Total pre & $4.22 \pm 1.16$ & $4.57 \pm 1.21^{*}$ & $4.43 \pm 1.26$ & $4.73 \pm 1.17$ & $4.08 \pm 0.95$ & $4.70 \pm 1.2$ \\
\hline \multicolumn{7}{|c|}{$\begin{array}{l}\text { 1) A statistical analysis was performed by paired t-test to compare between each control } \\
\text { group and each experimental group by each characteristic ( }(\mathrm{p}<0.05) \text {. } \\
\text { A, Not treated, control; B, Sauce for raw fish; C, Chokochujang, control; D, } \\
\text { Kochujang+Sauce for raw fish (1:1); E, Soy sauce, control; F, Soy sauce+Sauce } \\
\text { for raw fish (1:1). }\end{array}$} \\
\hline
\end{tabular}

\section{요 약}

본 연구는 여름철 식중독의 주원인균으로 알려져 있는 Vibrio parahaemolyticus와 Vibrio vulnificus를 대상으로 마 늘식초와 차 추출물을 이용해 제조한 생선회용 소스의 항균 활성을 평가하고, 실제 생선회에 적용 시켰을 때의 관능 
특성을 평가하기 위해 수행되었다. 제작한 생선회용 소스 는 시판 간장, 고추장과 비교했을 때 V.parahaemolyticus와 V. vulnificus에 대해 생육저해환을 생성하며 항균활성을 지니고 있음을 보여주었으며, 두 균주의 생육을 저해하였 다. 또한 생선회에서도 생선회용 소스가 살균효과를 나타 내는지 확인하기 위해 고추장-생선회용 소스, 간장-생선회 용 소스로 제작하여 광어회에 적용시켰을 때에도 두 균주의 생육을 뚜렷하게 저해하였음을 보여주었다. 생선회용 소스 를 실생활에서 회를 섭취할 때 쉽게 수용할 수 있을지 알아 보기 위해 관능평가를 실시한 결과, 고추장-생선회용 소스 및 간장-생선회용 소스가 시판 고추장 및 간장에 비해 전체 적으로 높은 점수를 얻음으로써 선호도가 높은 경향을 보였 다. 이 중 고추장-생선회용 소스는 조직감 측면에서 유의적 으로 우수하다는 평가를 받았으며, 간장-생선회용 소스는 외관, 조직감, 향미, 맛, 종합 기호도 등 모든 측면에서 유의 적으로 우수한 것으로 나타났다. 이상의 결과로부터 마늘 식초와 차추출물로 제작한 생선회용 소스는 V. parahaemolyticus 와 $V$. vulnificus에 대해 효과적인 살균력을 갖는 것으로 확인되었으며, 간장과 고추장에 활용할 경우 그 항균활성 으로 인해 생선회 섭취로 인한 식중독을 예방할 뿐만 아니 라 소비자의 만족도를 향상시켜 여름철 생선회 소비를 촉진 시킬 수 있을 것이라 판단된다. 더 나아가 여러 가지 소스에 적용할 수 있도록 기능성평가 및 관능평가를 실시하는 등 보완된 연구를 계속한다면 다양한 소스에의 활용이 가능할 것으로 판단된다.

\section{감사의 글}

본 연구에서 사용된 마늘식초는 강화군 농업기술센터에 서 제공받아 수행되었으며, 이에 감사드립니다.

\section{References}

1. Kim YM (1993) Contamination of shellfish with Vibrio vulnificus the present situation and countermeasures. J Food Hyg Saf, 8, S13-S21

2. Kim YM, Hur SH, Chang DS (1988) The growth of Vibrio vulnificus in meat homogenates of fish and shellfish. Korean J Fish Aquat Sci, 21, 80-84

3. Jun BY (1998) The epidemiological characteristics of food poisoning in Korea. Korean J Med, 55, 690-693

4. Park HO, Kim CM, Woo GJ, Park SH, Lee DH, Chang EJ, Park KH (2001) Monitoring and trends analysis of food poisoning outbreaks occurred in recent years in Korea. J Food hyg Saf, 16, 280-294
5. Yeom JC, Lee SJ, Oh ST, Ahn JC, Kim JH, Kyung YY (2006) Basic western cuisine. Baeksan publishing, Korea, p 354

6. Chae YC (2000) The study of classification sauce. Ulsan college Journal of research, 27, 493-505

7. Mochizuki E, Yamamoto T, Suzuki S, Nakazawa H (1996) Electrophoretic identification of garlic and garlic products. J AOAC Int, 79, 1466-1470

8. Vegetables and special crops division, Ministry for food, agriculture, forestry and fisheries (2009) The situations of major vegetables' processsing in 2008. Ministry for food, agriculture, forestry and fisheries, MAF 24626

9. Park JY, Kim JG (2009) Inhibitory effect of garlic on the growth of Aspergillus parasiticus. J Environ Health Sci, 35, 95-99

10. Branen J, Davidson PM (2000) Activity of hydrolysed lactoferrin against foodborne pathogenic bacteria in growth media: the effect of EDTA. Letters in Applied Microbiol, 30, 233-237

11. Chantaysakorn P, Richter RL (2000) Antimicrobial properties of pepsin-digested lactoferrin added to carrot juice and filtrates of carrot juice. J Food Prot, 63, 376-38012. Lipsky J (2000) Spicing up the value of steak with pre-seasoning. Meat Marketing and Technol, 8, 56-57

13. Jo C, Son JH, Son CB, Byun MW (2003) Functional properties of raw and cooked pork patties with added irradiated, freeze dried green tea leaf extract powder during storage at $4^{\circ} \mathrm{C}$. Meat Sci, 64, 13-17

14. Park CS (2000) Effect of pine needle and green tea extracts on the survival of pathogenic bacteria. Korean J Food Cook Sci, 16, 40-46

15. Roh HJ, Shin YS, Lee KS, Shin MK (1996) Effect of water extract of green tea on the quality and shelf life of cooked rice. Korean J Food Sci Technol, 28, 417-420

16. Oh DH, Lee MK, Park BK (1999) Antimicrobial activities of commercially available tea on the harmful foodborne organisms. J Korean Soc Food Sci Nutr, 28, 100-106

17. Ryu BH, Park CO (1997) Antioxidant effect of green tea extracts on enzymatic activities of hairless mice skin induced by ultraviolet B light. Korean J Food Sci Technol, 29, 355-361

18. Kim HJ (1999) A study on the antioxidative effect and antimicrobial activity of herb extracts. MS Thesis, Sungshin women's University, Korea, p 18

19. Xi D, Liu C, Su YC (2012) Effects of green tea extract on reducing Vibrio parahaemolyticus and increasing shelf 
life of oyster meats. Food Control, 25, 368-373

20. Chung SH, Yoon KH (2008) Antimicrobial activity of extracts and fractions of green tea used for coarse tea. J Korean Soc Food Sci Nutr, 37, 1382-1388

21. Cho SY, Choi JH, Ham SS, Oh DH (2005) Antimicrobial activities of green tea extract and fractions on the $E$. coli O157:H7. J Food Hyg Saf, 20, 48-52

22. Mbata TI, Debiao LU, Saikia A (2008) Antibacterial activity of the crude extract of Chinese green tea (Camellia sinensis) on Listeria monocytogenes. African
J Biotechnology, 7, 1571-1573

23. Park CS, Cha MS, Kim ML (2001) Changes in the antibacterial activity of green tea extracts in various $\mathrm{pH}$ of culture broth against Staphylococcus aureus and Salmonella typhimurium. Korean J Food Preserv, 8, 206-212

24. Kim JD, Kim MY, Jung SJ, Seo HJ, Kim EO, Lee SY (2005) Development of Gochujang for controlling $V$. parahaemolyticus with green tea and natural products. Life Sci, 15, 783-789 